\title{
STUDIES DETERMINANTS OF ECONOMIC STRUCTURAL CHANGE AND MIGRATION SURPRISES IN MALUKU PROVINCE
}

\author{
Erly Leiwakabessy \\ Faculty of Economics, University Pattimura \\ fekon@unpatti.ac.id \\ Jani Effendy \\ Faculty of Economics, University Pattimura \\ janieffendy77@gmail.com \\ Jacobus Cliff Diky Rijoly \\ Faculty of Economics, University Pattimura \\ j.rijoly@fekon.unpatti.ac.id
}

\begin{abstract}
The aim of this research is; 1) To test and analyze the influence of local government spending towards economic transformation has occurred, the transformation of labor, per capita income and population migration, 2) To test and analyze the influence of local government investment to economic transformation, the transformation of labor, per capita income and immigration, 3) To test and analyze the effects of regional economic transformation on the transformation of employment, investment and immigration, 4) To test and analyze the effect of the transformation of labor against immigration per capita income and population, 5) To test and analyze the influence of income per capita of the population migration.

This research was conducted in the province of Maluku, by taking data on the eight districts of the city for five years. The data were analyzed panel data, and testing was conducted using structural equation modeling.

The results of structural equation analysis shows that government spending affect the transformation of the economy, per capita income and immigration, but no direct impact on the transformation of the workforce. Investment effect on economic transformation, the transformation of labor, per capita income and population immigration. Economic transformation effect on the transformation of labor, per capita income and population immigration. Labor transformation effect on per capita income, but does not affect the immigration population. Per capita income affect the immigration population in the province of Maluku.
\end{abstract}

Keywords: local government spending, Migration Shock, the transformation of labor 


\section{Introduction}

Implementation of regional autonomy is a manifestation of the people's demand to eliminate the development gaps due centralized policies, thus providing greater opportunities for fiscal management at the local level and further decline in central government control. It is intended to be more highly regional role in managing the authority and responsibility of financing sources. Sources of financial balance normatively according to the latest legislation is an improvement on the previous provisions were deemed not as perfect as the financial division felt unjust.

The main thing that is a constraint in the implementation of regional autonomy is the transfer source of help and donations from the center to the regions, where the financial balance patterns that indicate the occurrence of the fiscal gap, either horizontal (inter-regional and regional) and vertical (between central and local). Basic financial balance for the purpose of equitable allocation of resources to finance the activities are increasing. As is understood that all levels of government requires the availability of resources for the administration and development and service to the community. The local government in the framework of governance, the implementation of development and service to the community, then there are five function according to Davey (1988), namely (1) the provision of services, (2) function of settings, (3) the function of development, (4) the function of representation and (5) functions of coordination and planning.

Development planning with emphasis on the industrial sector performed nationally and regionally, to support fiscal policy instruments used, and monetary policies as well as the budget allocation policy of deregulation in the banking sector for infrastructure development of industrial sector. While it seems development policy to prioritize the industrial sector (the secondary), but the association and its impact direct or indirectly, must be experienced by the agricultural sector (primary) and services sector (tertiary).

Hopefully, by the growth of the industrial sector in a sustainable manner, able to absorb the labor force continues to grow due to an increase in the labor force as a result of population growth. Conditions of labor force growth is always greater than the growth of employment resulting in unemployment that is difficult to overcome. Economically unemployment reduction or absence of income which in turn lead to poverty and a decline in government revenue from taxes, decreased production capacity which could further decline in push revenue national and regional income. Additionally socially unemployment also can cause various problems such as crime are troubling. If compare, the decline in gross domestic product as a result of the increase in unemployment is smaller than the increase in gross domestic product as a result of the use of capital-intensive industrial sector, thus the overall gross domestic product continues to increase. Thus in the economy has always sought an increase or growth in gross domestic product that is big enough to drown out macroeconomic problems that exist.

Cooperation between the various parties in the center through the exchange of information, resources, knowledge and technical experience will reduce transaction costs and further improve competitiveness, including accelerating the learning process and technical innovation (Nadvi, 1995; Visser, 1999). Porter (2000) suggested that the government in thinking about national and regional competitiveness is more focused on the overall economy, the policies at the national level has a more dominant influence. In a global economy macro policy is important but not sufficient. Obligations of the government should be more real and inevitable to influence the economy on a more micro level, such as reducing barriers to the development of existing centers and the creation of new centers resulting transformation economic and labor which would encourage economic growth and prosperity.

There is no denying that the economic development be planned including decentralization indicate economic development nationally and to the province of Moluccas. 
This fact in recent years must not be separated from an increase in fiscal resources continues to raise the rate of economic growth.

Gross Regional Domestic Product (GDP) of the province of Moluccas. Despite these social tragedies that hit Moluccas province that devastated economic infrastructure area, as well as social infrastructure and other public facilities, so that between 1999 and 2001 the economy Moluccas experienced negative growth, while other regions in the country have started to come out of its financial crisis and the economic crisis occurred since 1998. In 2002, began a resurgence of economic Moluccas, where there is positive growth, although still thin and slow. The interesting thing is the improvement of regional economic growth this happened, so that in 2006 economic growth rate is above the national economic growth, although in 2007 and so the rate of growth of this area back under the national economic growth.

Contribution of the sector is still dominated by the three main sectors, namely agriculture, trade, hotels and restaurants, as well as the services sector. Sector agriculture provides a substantial contribution, in 2003 and 2004 contribution amounted to $35.72 \%$, then increased to $35.75 \%$ in 2005 , subsequently going on trend decline in the sector's contribution to the year 2007. This indicates an improvement to conditions, so other sectors are also showing progressin contributions. Trade, hotels and restaurants contributions in 2003 amounted to $25.26 \%$, continue to increase until 2007.

Moluccas Maluku province with an area large enough and sufficient potential available, has a number of relatively small population of around 1.4 million people, and about 867517 inhabitants of which the working-age population and a workforce of about 531780 , while total employment absorbed about 455337 people, meaning the open unemployment rate in 2007 was 76443 , or $14.37 \%$. Most of the workers who work / absorbed in the agricultural sector, which amounted to $78.26 \%$ were in the manufacturing sector amounted to $3.22 \%$, and the trade, hotels and restaurants amounted to $10.40 \%$, the rest are scattered in other sectors by $8,13 \%$.

Economic sectors biggest contributor to the GDP as well as a strategic sector, that sector contribution to the GDP and absorbing labor large great anyway, but there is also a small but accounts for labor absorption is large enough, this indicates the possibility of development prospective.

Absorbing sectors manpower in Moluccas province is a major agricultural sector, the services sector, trade, transport sector and industrial sector. It draws from the data above picture is happening employment trends were very volatile in all sectors. The agricultural sector for example, from 2004 to 2006 decline in employment is quite striking that the widened from 293 749191637 people, meaning a decline of 102112 people or $85.35 \%$. Furthermore, in 2007 and 2008 saw an increase in employment, but still relatively thin / small and the figures have not been as big as the base year (2003) as many as 197992 people (2007) and 226987 (2008). The service sector showed very different trends in the agricultural sector, where an increase in employment of 2003 amounted to 57735 people became 64009 people in 2004 or increased by 6274 persons or by $0.11 \%$. Later in the following years (2005 to 2008) a decline in employment. The trade sector showed a fluctuating trend and tends to decrease whereas the transport sector shows a fluctuating trend and increased. Furthermore, the industrial sector showed a very interesting phenomenon, in 2004, an increase in employment amounted to $40.45 \%$ and then declined in 2005 decreased very dramatically by $(75.87 \%)$, in 2006 there was a slight increase in absorption, but returned decline in 2007, even in 2008 the decline of more than $100 \%$, or $104.323 \%$.

The phenomenon of the economic sector contribution to the GDP and employment in the data (tables 1 and 2) above is very interesting to be studied and analyzed in order to know whether the wage, sectoral shifts or economic transformations that affect it. The following figure shows, the ratio of wages per worker by sector in Moluccas Province in 2004 and 2007 (Figure 1). 
Figure 1. Comparison of Wages Per Workers (Million USD) by Sector Moluccas Province in 2004 and 2007.

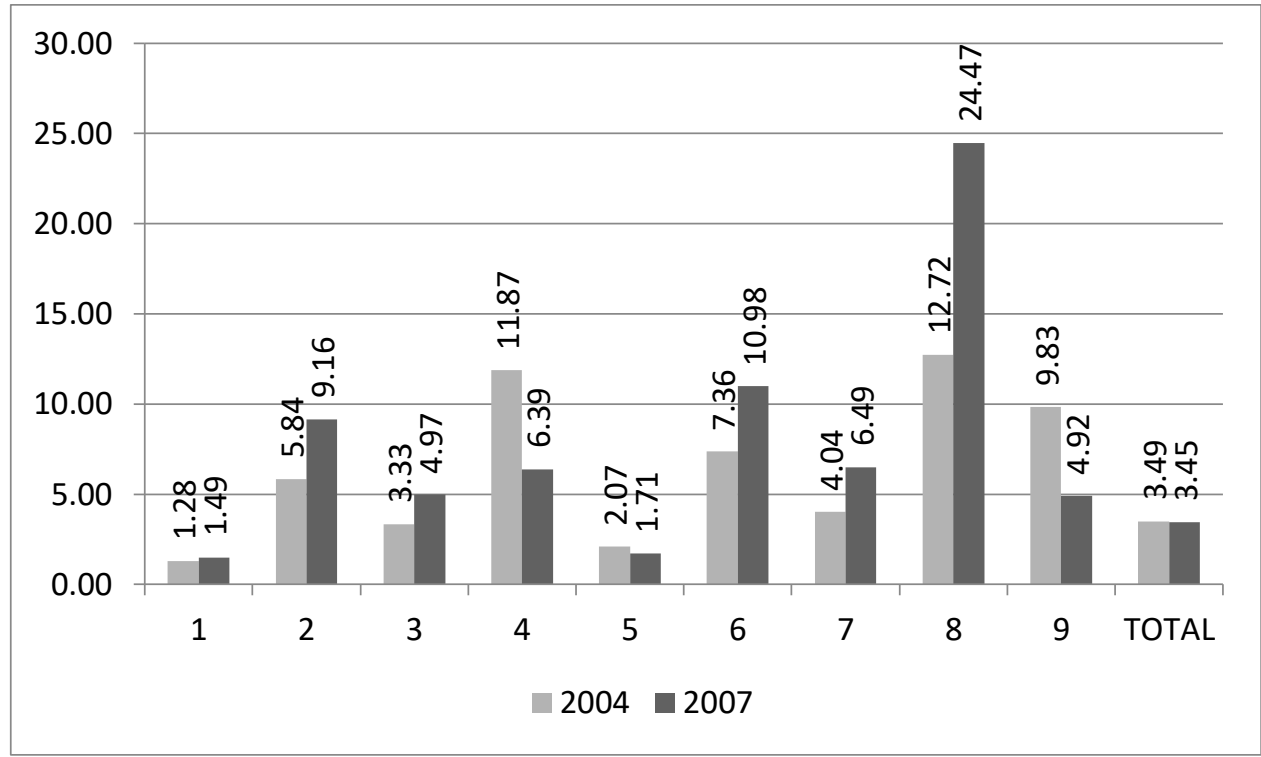

Figure 1 shows a comparison of wages per worker in 2004 and 2007 in the province of Moluccas. Agriculture, mining and quarrying sector, industrial sector, the sector of trade, hotels and restaurants and financial sector, leasing and business services showed growth vigorous wage comparisons work while the construction sector and the services sector showed a decline.

It is seen that there is no significant improvement in employment that indicate poor job creation in the country, especially in regions including Moluccas province. This is understandable because the employment generation in the country is only possible when able to boost economic growth. Increased economic growth is only possible through the creation of business and investment climate conducive, so that entrepreneurs can take part in economic activities. Efforts to preserve existing jobs and even create new employment fields and to improve the conditions and terms of employment towards decent work, thus the necessary economic growth of $7 \%-8 \%$ per year to absorb the existing unemployed into the job market.

The industrial sector has a dependency that is linked to the agricultural sector. The development of the industrial sector will be accompanied by a decrease in profit if it is not supported by the development of the agricultural sector. It is caused by the industrial sector does not produce food. The industrial sector can not develop without the support of the development of the agricultural sector. From the description easy to understand why the development of the industrial and agricultural development occur simultaneously and why in a country or region if the agricultural sector stagnated, the industrial sector was not experienced significant development. The existence of harmony between the growth of the agricultural sector with overall economic growth showed that the factors affecting the growth of the agricultural sector is linked to the overall economic policy.

\section{Theoretical of development}

\section{a. Government Spending, Fiscal Policy and Regional Autonomy}

There is a difference is striking between the behavior of economic actors, typically households and businesses conduct their activities based on the existing revenue, while the government expenditures, and subsequently obtained revenue as a consequence of its expenditure to finance infrastructure projects of economic, social and public facilities more.

The role of government in the economy always contain a lot of controversy both from the aspect of macro and micro aspects. In the micro aspects, the active role of the government 
to regulate competition, providing the infrastructure and education and income redistribution, although opposed by those who advocate for limiting government intervention in order to improve efficiency. While the macro aspects are emphasized on the role of the government to smooth the business cycle with the tools of fiscal policy that is using the power of taxation and spending to increase aggregate spending. Although there are other sides who claim that government spending is not able to stabilize the economy. But one thing is becoming a deal and a reality that can not be denied is that the government is an important actor in the economies of all countries even at all levels of government. The government can influence the economy through two channels of policy; (1) fiscal policy and (2) the monetary policy. Fiscal policy refers to the government's behavior in the areas of spending and taxation, in other words, the budget policy. Budget policy mainly focused on the expenditure budget which is currently under Regulation Ministry of the Interior (PERMENDAGRI PERMENDAGRI 13 of 2006 and 59 of 2007) breaks in indirect expenditures and direct spending. General government fiscal spending is divided into three categories; (1) policies relating to government purchases of goods and services; (2) policy concerning taxation and (3) policy concerning the transfer payments (such as unemployment compensation, social security benefits, welfare payments and annuities).

Some literature Science State Finance or Public Economics provides a definition of the concept of regional government finances, which is often called the local finance or fiscal federalism or decentralized fiscal (fiscal decentralization). Understood here that fiscal decentralization is all authority, the right and responsibility to manage the financial affairs of the area both the revenue side and the expenditure side to finance government activities and execution of development and community service in the areas more efficiently and effectively.

Development of concepts related to finance the state (including local government finance) more touches and affects all aspects of the economy both in terms of the macro and the micro level. In the framework of regional autonomy that allows the management of state finances in the region must accommodate and provide space for the development of macro policies at the local level that causes economic transformation, economic growth, income distribution due to the transformation of labor and the creation of economic stability.

Two of the government's fiscal policy instruments, namely instrument taxes and transfers. Tax implications for the decline in public revenue while transfers will tend to increase incomes. According Kniesner and Ziliak (2002), the income tax creates a guarantee to minimize the variability of disposable income (disposable income) and consumption. By using frameworks (frameworks) derived from empirical literature consumption assurance, based on data from a panel study of income dynamics can be tested the effect of income tax the federal government made in the 1980s about the stabilization of consumption automatically. The result is that with the implementation of the income tax would reduce stability of consumption of about 50 percent. While shifting welfare costs substantially after the tax system applied to households whose incomes are large and relatively scared of risk (risk-averse) but many more on the type of household that simple.

Implementation of fiscal policy by governments typically use the instrument of taxes and transfers, the impact of these two different instruments. Lowers tax revenues, while public transfers increase people's income, for example taxation at the provincial and district / city very much and it is known in general, while the transfer is an example of output price subsidies. As Chambers and Quiggin (2005) examine the comparative static output price subsidies for companies with monotonic preferences against uncertain production, concluded that the existence of price subsidies will increase output then deals. Improvement occurred deals for growers / producers are encouraged to increase the use of inputs, which in turn will boost demand for inputs. The subsidy given by the government require large government spending and rising. 


\section{b. Inter sector linkages and Economic Transformation}

The economic development is the production activities of economic sectors that are interrelated and do not stand alone. Each production process usually requires input supplied direct role in the country or imported from abroad, an industry that produce or produce certain inputs, requires input coming from other sectors to the production process. Industries become intertwined with each other by using the product between capital goods, resulting interdependence between sectors.

\section{c. Population migration}

The general term for the movement of people in the population demographics are more specifically mobility or territorial mobility which usually implies motion spacial, physical and geographical (Shryllock and Siegel, 1973, in Rusli.1996: case 136). This includes both dimensions to people's movements on a permanent or non-permanent dimension. Migration is a permanent resident dimensional motion, while the motion-dimensional non-permanent residents consisted of circulation and communication.

Another definition, migration is the movement of people for the purpose of settling from one place to another beyond the limits of political / public or administrative border / boundary within a country. Migration difficult to measure due to migration can be defined in various ways and is an event that may be repeated several times throughout his life. Almost all definitions using the criteria of time and space, so that the displacement is included in the migration process at least considered semi-permanent and across the boundaries of geographic location.

\section{d. Hypotheses}

Government spending is a research variable formed from direct expenditure and indirect expenditure the government, which is based on theory and previous research may affect the economic transformation, the transformation of labor, per capita income and in labor migration. Therefore, the first hypothesis in this study are:

H1. Government expenditures are directly or indirectly affect the economic transformation, the transformation of labor, per capita income and in labor migration.

$\mathrm{H} 2$. Investing directly or indirectly affect the economic transformation, the transformation of labor, per capita income and in labor migration

H3. Economic transformation, directly or indirectly affect the transformation of labor, per capita income and in labor migration

H4. The transformation of the workforce directly or indirectly affect per capita income and in labor migration

H5. The per capita income in directly affect labor migration

\section{Research Method}

\section{a. Research variable}

The research variables is an abstract concept that can be measured. Abstract concept that can be directly measured or manifest called the observed variables, and also there is an abstract concept that can not be measured directly or unobserved variables, or often called latent or constructs (Ghozali, 2008).

Kerlinger (2000) define variables as symbols / emblems by which we attribute to the number or value. These variables need to be identified in order to make it easier to analyze according to research problems. Variables are generally grouped into two independent 
variables (independent variable) and the dependent variable (dependent variable). The independent variables and the dependent variable was tested in this study can be seen in Table 1 below.

Table 1. Independent Variables and Dependent Variables

Independent Variables

Govermnet Expenditure

Investation

\section{b. Data Analysis Techniques}

Hypothesis testing is done by using analysis Structura Equation Model (SEM). The use of this analytical tool for SEM allows to do three activities simultaneously, namely checking the validity and reliability of the instrument (equivalent to factor confirmatory analysis), the test model of the relationship between the latent variables (equivalent to analysis Path), as well as get a useful model to estimate (equivalent to structural model or regression analysis) (Solimun, 2002).

Estimation of the general structural model using a mathematical formulation as follows (Ghozali, 2005) :

$$
\mathrm{Y}=\mathrm{By}+\Gamma \mathrm{x}+\zeta
$$

Where: $\mathrm{Y}$ is the vector of endogenous variable (dependent), $\mathrm{x}$ is a variable vector exogenus (independent), $\zeta$ is a vector disturbance (disturbance errors), while $B$ and $\Gamma$ is the coefficient matrix.

Joreskog stated that the general structural equation model consists of two parts: 1) the measuring section, which connects the observed variables to a latent variable by confirmatory factor, and 2) structural parts, which connect between the latent variables through a system of structural equations (Ghozali, 2004). Model measurements (measurement model) is intended to confirm whether the indicators used can confirm a factor or latent variables. Meanwhile, structural model aims to determine the causal relationship between latent variables in government spending, investment, economic transformation, the transformation of labor, per capita income and in migration was marked by the arrows, as shown in Figure 2. the following:

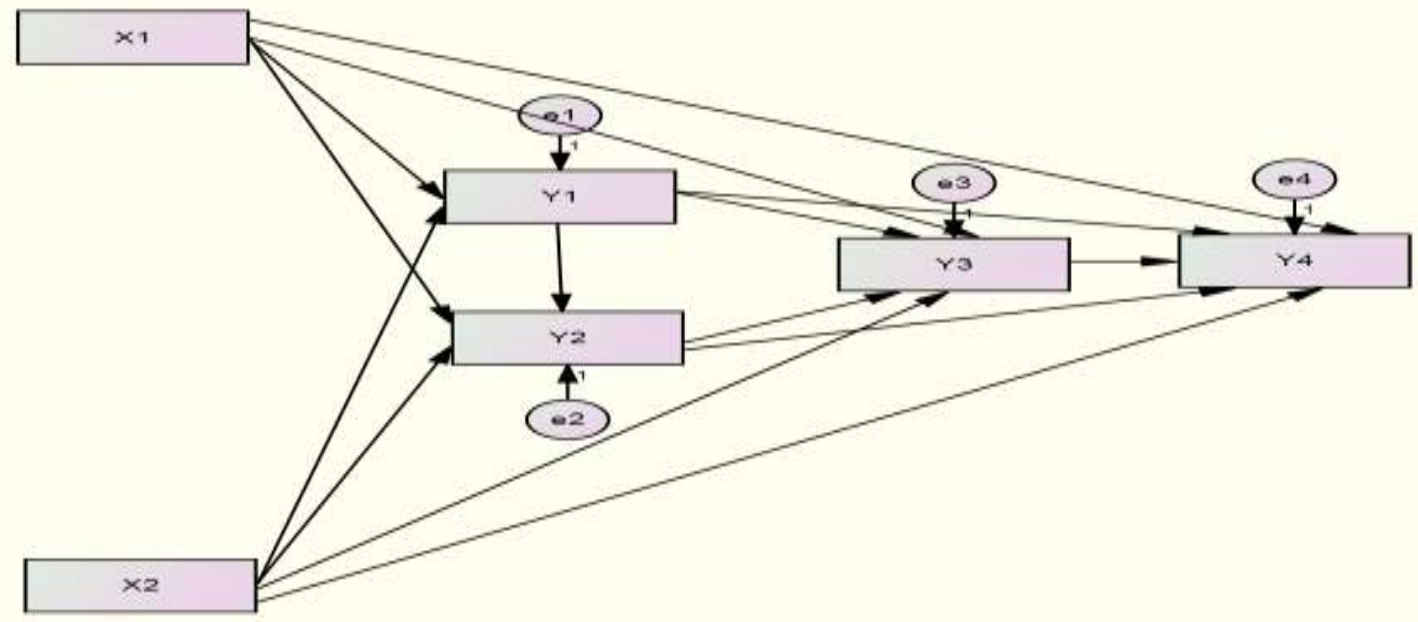

Figure 2 : Structural Model 
Of the six latent variables, as shown in the picture above, there are two exogenous variables (independent) that government spending $\left(\mathrm{X}_{1}\right)$, Investment $\left(\mathrm{X}_{2}\right)$ because this variable was not influenced by antecedent variables (before). The four other variable is the endogenous variable (dependent) since this variable is influenced by antecedent variables.

Based on Figure 2 above it can be arranged structural equation model in detail described in the previous chapter are: Based on Figure 1 above it can be arranged structural equation model in detail described in the previous chapter are:

$\mathrm{Y}_{4}=\lambda_{0}+\lambda_{1} \mathrm{Y}_{1}+\lambda_{2} \mathrm{Y}_{2}+\lambda_{3} \mathrm{Y}_{3}++\lambda_{4} \mathrm{X}_{1}+\lambda_{5} \mathrm{X}_{2}+\mu_{4}$

$\mathrm{Y}_{3}=\alpha 0++\alpha_{1} \mathrm{Y}_{1}+\alpha_{2} \mathrm{Y}_{2}+\alpha_{3} \mathrm{X}_{1}+\alpha_{4} \mathrm{X}_{2}+\mu_{3}$

$\mathrm{Y}_{2}=\beta_{0}+\beta_{1} \mathrm{Y}_{1}+\beta_{2} \mathrm{X}_{1}+\beta_{3} \mathrm{X}_{2}+\mu_{2}$

$Y_{1}=\gamma_{0}+\gamma_{1} X_{1}+\gamma_{2} X_{2}+\mu_{1}$

Information:

$\mathrm{X}_{1}=$ Government Spending

$\mathrm{X}_{2}=$ Investment

$\mathrm{Y}_{1}=$ Economic Transformation

$\mathrm{Y}_{2}=$ Transformation Workforce

$\mathrm{Y}_{3}=$ Income Per Capita

$\mathrm{Y}_{4}=\mathrm{In}$ Migration

$\gamma_{1}, \gamma_{2},=$ coefficient of independent variables on the dependent variable $\mathrm{Y}_{1}$

$\beta_{2}, \beta_{3},=$ coefficient of independent variables on the dependent variable $Y_{2}$

$\alpha_{3}, \alpha_{4},=$ coefficient of independent variables on the dependent variable $\mathrm{Y}_{3}$

$\lambda_{4}, \lambda_{5},=$ coefficient of independent variables on the dependent variable $\mathrm{Y}_{4}$

$\beta_{1}, \alpha_{1}, \alpha 2, \lambda_{1}, \lambda_{2}, \lambda_{3}=$ coefficient influence the dependent variable on the dependent variable more

$\mu_{1} \ldots \ldots . . \mu_{4}=$ error term

Structural equation model was processed with the aid of a computer program packages. This analysis has been widely used by researchers for the operationalization have many packages available computer program, EQS, LISREL and AMOS. In this experiment, the AMOS program (Analysis Of Moment Structure). AMOS developed by J.Arbukle to process models are multidimensional research and tiered (Ferdinand, 2002) :

Furthermore, the conformance test (fit index) and the statistical models to measure the goodness of fit or the degree of correspondence between the hypothesized model with existing data. There is some fit index is used, among other things:

1. Chi-Square $\left(\mathrm{X}^{2}\right)$

The most fundamental measurement tool to measure the overall fit is likehihood ratio ChiSquare. Chi-Square it is very sensitive to the sample size used, as it was when the sample size is large enough (over 200 samples), then statistical test Chi-Square must be accompanied by other test tools (Hair et al., 1998). The model was tested in a nice vantage point to satisfactory when Chi-Square is low $\mathrm{X}^{2}$ The lower the better model $\left(\mathrm{X}^{2}=0\right.$, means there is no difference between the estimates population covariance is equal to the sample covariance, Ho accepted) and received by the probability of the cut-off value of $p<0.05$ or p> 0.10 (Hulland et al., 1996 in Ferdinand, 2002).

2. The Root Mean Square Error Approximation (RMSEA)

RMSEA is an index that can be used to compensate for the Chi-Square statistic in a large sample (Baumgartner \& Homburg, 1996). RMSEA value shows the goodness-of-fit can be expected when the model is estimated in the population (Hair et al., 1998). RMSEA value $\leq 0.08$ is an index for the inadmissibility of a model that shows a close fit of the model was based on the degrees of freedom (Broene \& Cudeck, 1993 in Ferdinand, 2002).

3. Goodness of Fit Index (GFI) 
Suitability index (fit index) will calculate the weighted proportion of the variance in the sample covariance matrix described by the covariance matrix of the population estimation (Bentler, 1983; Tanaka and Huba, 1989 in Solimun (2002)). GFI is a non-statistical measure that has a range of values between 0 (poor fit) to 1 (perfect fit). A high value in this index shows a "better fit" (Hair et al., 1998).

4. Adjusted Goodness-of-Fit Index (AGFI)

When GFI analogous to $\mathrm{R}^{2}$, the analog AGFI of Adjusted $\mathrm{R}^{2}$ in regression. There is no indication that agreed by experts on how the value AGFI qualified that compliance (fit) models are met, but researchers have used a value of 0.80 as the minimum acceptance value (Sharma, 1996). Neither GFI nor AGFI is weighted criteria that take into account the proportion of the variance in a sample covariance matrix.

5. The Minimum sample Discrepancy Function (CMIN / DF)

CMIN divided by the degree of free will produce an index CMIN / DF, which is generally used as an indicator to measure the level fitnya model. CMIN / DF is nothing but the chisquare statistic, ${ }^{2}$ divided DF its so-called relative $X^{2}$. $X^{2}$ Relative Values less than 2.0 or even sometimes less than 3.0 is indicative of acceptable fit between model and data (Arbuckle, 1997 in Solimun 2002).

\section{Results And Analysis}

\section{a. Validity and Reliability Variables}

In testing the validity and reliability of the software Amos 16 conditions that must be met is standardized loading estimate should be equal to 0.5 or more (Ghozali, 2008). From the test results also showed that there is the same thing, as evidenced by the value Loading Factor (LF) construct high, then the value of high loading on a factor (latent constructs) showed that they Convergen at one point. Which in this study the value of the final stages of the loading factor respective latent constructs are all significant with a value above 0.5. (Appendix 2-23).

Reliability testing using the results issued by the software AMOS 16. In this test also using Cronbach alpha as a measure of reliability, with the proviso $\alpha \geq 0.6$. The test results as shown in Table below:

Table. 2: Reliability Calculation Results Table Variables

$\begin{array}{lcc}\quad \text { Variable } & \alpha-\text { cronbach } & \text { Description } \\ \text { Goverment Spending } & 0,830 & \text { Good } \\ \text { Invesment } & 0,985 & \text { Good } \\ \text { Economic Transformation } & 0,992 & \text { Good } \\ \text { Transformation of Labour } & 0,612 & \text { Good } \\ \text { Income per Capita } & 0,695 & \text { Good } \\ \text { In Migrasi } & 0,976 & \text { Good }\end{array}$

Source: Results of 2011 if the primary data

1. Test Data Outliers

Outlier is the condition of observation of the data that has unique characteristics that look very different from the observations of others and appear in the form of extreme value, either for a single variable or variables combination (Hair et al, 1998, in Ghozali, 2008). Detection of multivariate outliers done with regard to the value mahalanobis distance. The criteria used is based on the value of chi squares is the degree of freedom in 1402 at a significant level of 0.001 . Value Mahalonabis distance $x^{2}(1402,0,005)=140.1690$. This means all the cases that have mahalanobis distance greater than 140.1690 is multivariate outliers. From the results issued by the AMOS program 16 can be seen that the value mahalanobis nothing above 140.1690, it can be concluded there is no outlier in the data. Check that no data outliers can also be performed by Mahalanobis distance, and if the distance is significant ( $p$ 
$<0.05)$, then it is said to be outliers. Testing is performed in conjunction with SEM analysis using AMOS software 16. It is seen that all the data is greater than 0.05 , it can be concluded there are no data outliers.

\section{Normality Test}

According Solimon (2002), that the normality assumption in SEM analysis is not too critical when the number of observation data of more than 100 pieces, especially if the variable used is the scale ratio (numeric) because according to the theory of the central limit (central limit theorem) for a number of observations were great approximately normally distributed.

\section{b. Estimation Results In Determinants of Population Migration}

Furthermore, the simultaneous testing of all these factors, namely; government spending, investment, economic transformation, the transformation of labor and per capita income by using structural equation. The relationship between the factors with each indicator can be seen in Figure 3 below.

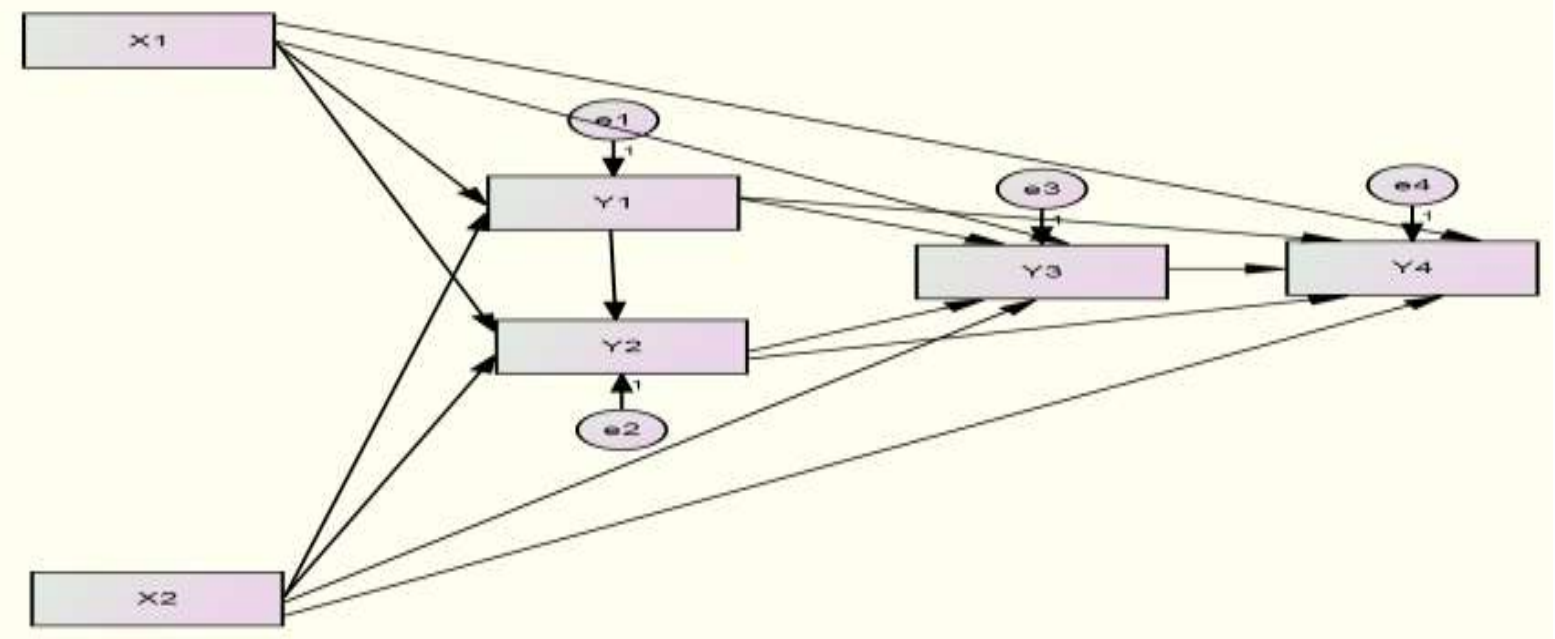

Figure 3. Causal Relationship Model Research

Computational results show that there is a criterion of goodness of fit indices were not met. The result is as shown in Table 3 below:

Table 3: Criteria Computing Goodness of fit indices

\section{Criteria}

Chi-Square

Sig. Probability

CMIN/DF

RMSEA

GFI

AGFI

Model Testing Research

$$
\text { Cut-off Value }
$$

Small Expected
$\geq 0,05$
$\leq 2,00$
$\leq 0,08$
$\geq 0,90$
$\geq 0,80$

$\geq 0,80$
Computational Result

3.558

0,001

1,985

0,07

0,923

0,819
Description

Good

Good

Good

Good

Good

Good

Source: Results of 2011 if the primary data

The results of the tests with confirmatory analysis and SEM above has shown that the model developed in this study may be acceptable depending on the model fit. Results of computation of variables in this model shows that government expenditure variable $\left(\mathrm{X}_{1}\right)$ has no significant effect on the variable transformation of labor $\left(\mathrm{Y}_{2}\right)$ and variable transformation of labor does not affect the variable in migration $\left(\mathrm{Y}_{4}\right)$. However, most of the 
variables found to have significant influence. The complete results of the computations can be seen in the table below.

Table 4 : Key Determinants Variable Model Research

Indicators

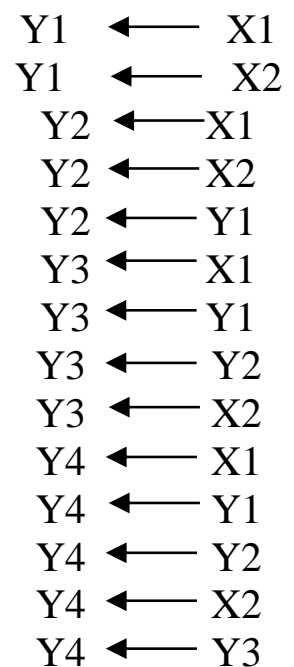

$\mathrm{LF}$

55.801

.966

11.082

.527

.537

.528

.015

.024

.025

.623

.024

.002

.531

.751
$C, R$

5.574

4.061

1.167

2.586

5.000

2.233

9.060

13.217

9.265

2.425

5.723

.395

2.448

3.300
T table

$(\alpha=5 \%)$

1,96

1,96

1,96

1,96

1,96

1,96

1,96

1,96

1,96

1,96

1,96

1,96

1,96

1,96
Remarks

Significant

Significant

Not

Significant

Significant

Significant

Significant

Significant

Significant

Significant

Significant

Tidak

Significant

Significant

Source: Results of 2011 if the primary data

Based on Table 4 above, can be described the research model is equipped with a large coefficient of each variable as in the following figure.

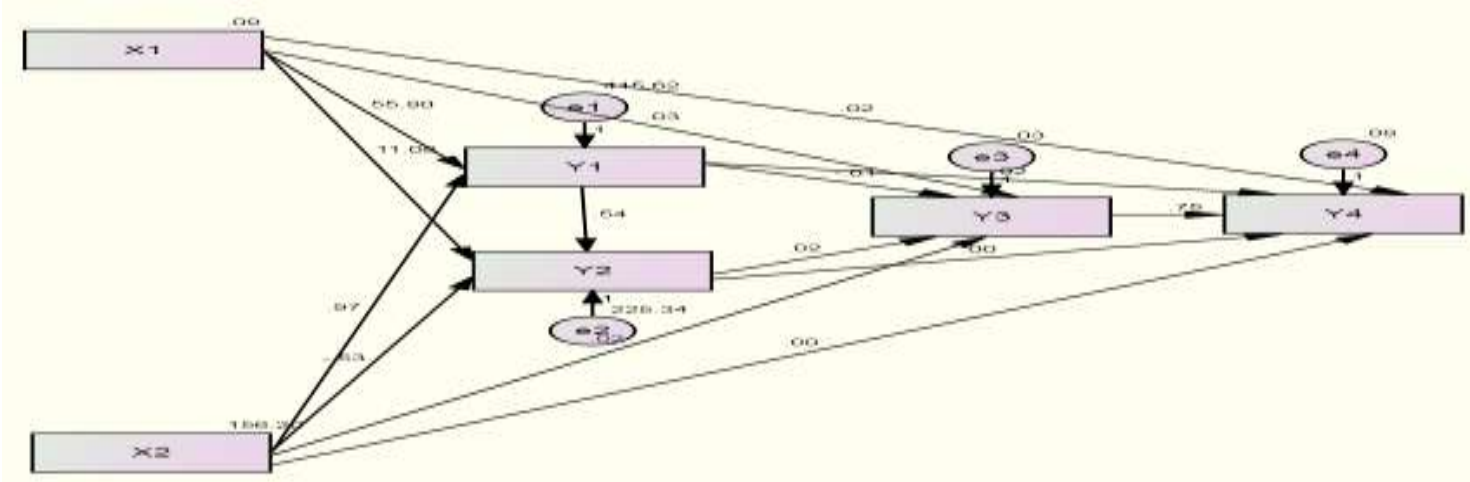

Figure 4. Research Model Estimation Results

Based on the research results obtained, as illustrated in Table 4 and Figure 3 above shows almost all the studied variables have positive influence and significant impact on other variables, there are only two variables showed no significant effect of variable government expenditure $\left(\mathrm{X}_{1}\right)$ has no significant effect on the variable transformation of labor $\left(\mathrm{Y}_{2}\right)$ and variable transformation of labor does not affect the variable in migration $\left(\mathrm{Y}_{4}\right)$. , The results of the above study showed that almost all of the research hypothesis is proven. As for proving a hypothesis based on the results of the study are as follows:

$\mathrm{H}_{1}$. Government expenditures are directly or indirectly affect the economic transformation, the transformation of labor, per capita income and in labor migration, it is based on research results could be concluded most of the first hypothesis is proven, and the only effect of government spending on the transformation of labor which is not proven. 
$\mathrm{H}_{2}$. Investing directly or indirectly affect the economic transformation, the transformation of labor, per capita income and labor migration in the hypothesis is proved.

$\mathrm{H}_{3}$. Economic transformation, directly or indirectly affect the transformation of labor, per capita income and labor migration in the hypothesis is proved.

$\mathrm{H}_{4}$. The transformation of the workforce directly or indirectly affect per capita income and labor migration in the study could be concluded based on the results of most of the hypothesis is proved, and the only effect of the transformation in labor migration which is not proven.

$\mathrm{H}_{5}$. The per capita income directly affect labor migration in the hypothesis is proved.

\section{Effect of Direct and Indirect}

Direct and indirect influence of each variable at 5:48 the following table:

table 5 Effect of Direct and Indirect Determinants In migration

$\begin{array}{ccccccc}\text { Effect of } & \text { Variable } & \mathrm{X}_{1} & \mathrm{X}_{2} & \mathrm{Y}_{1} & \mathrm{Y}_{2} & \mathrm{Y} 3 \\ & \mathrm{Y}_{1} & 55,8 & 0,966 & 0 & 0 & 0 \\ \text { Total } & \mathrm{Y}_{2} & 41,1 & 1,27 & 1,732 & 0 & 0 \\ & \mathrm{Y}_{3} & 0,674 & 1,063 & 0,028 & 0,024 & 0 \\ & \mathrm{Y}_{4} & 1,6 & 0,545 & 0,024 & 0,020 & 0,751 \\ & \mathrm{Y}_{1} & 0 & 0 & 0 & 0 & 0 \\ \text { Indirect } & \mathrm{Y}_{2} & 30 & 0,519 & 0 & 0 & 0 \\ & \mathrm{Y}_{3} & 0,146 & 1,039 & 0,013 & 0 & 0 \\ & \mathrm{Y}_{4} & 1,575 & 0,014 & 0 & 0,018 & 0 \\ & \mathrm{Y}_{1} & 55,8 & 0,966 & 0 & 0 & 0 \\ \text { Direct } & \mathrm{Y}_{2} & 11,1 & 0,527 & 0,537 & 0 & 0 \\ & \mathrm{Y}_{3} & 0,528 & 0,024 & 0,015 & 0,024 & 0 \\ & \mathrm{Y}_{4} & 0,623 & 0,531 & 0,024 & 0,002 & 0,751\end{array}$

Source: The results of primary data processing in 2011 (Annex 20)

From the table above it can be seen that there is a direct effect of government spending $\left(\mathrm{X}_{1}\right)$ with the transformation of the economy $\left(\mathrm{Y}_{1}\right)$ of 55.8, the transformation of labor $\left(\mathrm{Y}_{2}\right)$ of 11.1, the income per capita $\left(\mathrm{Y}_{3}\right)$ of 0.528 , and against in migration 0.623 . Indirect effects of government spending $\left(\mathrm{X}_{1}\right)$ on the transformation of the workforce $\left(\mathrm{Y}_{2}\right)$ of 30 , the income per capita $\left(\mathrm{Y}_{3}\right)$ amounted to 0,146 and the 1,575 in migration. The total effect of government spending $\left(\mathrm{X}_{1}\right)$ with the transformation of the economy $\left(\mathrm{Y}_{1}\right)$ of 55.8, the transformation of labor $\left(\mathrm{Y}_{2}\right)$ amounted to 41.1 , the income per capita $\left(\mathrm{Y}_{3}\right)$ amounted to 0.674 and against in migration $\left(\mathrm{Y}_{4}\right)$ of 1.6.

The immediate effect of investment $\left(\mathrm{X}_{2}\right)$ with the transformation of the economy $\left(\mathrm{Y}_{1}\right)$ of 0.966 , the transformation of labor $\left(\mathrm{Y}_{2}\right)$ amounted to 0.527 , the income per capita $\left(\mathrm{Y}_{3}\right)$ of 0.024 , and the in migration $\left(\mathrm{Y}_{4}\right)$ to 0,531 . Indirect effects of investment $\left(\mathrm{X}_{2}\right)$ on the transformation of the workforce $\left(\mathrm{Y}_{2}\right)$ amounted to 0.519 , the income per capita $\left(\mathrm{Y}_{3}\right)$ amounted to 1.039 and against in migration $\left(\mathrm{Y}_{4}\right)$ 0.014. The total effect of investment $\left(\mathrm{X}_{2}\right)$ with the transformation of the economy $\left(\mathrm{Y}_{1}\right)$ of 0.966 , the transformation of labor $\left(\mathrm{Y}_{2}\right)$ of 1.27 , the income per capita $\left(\mathrm{Y}_{3}\right)$ amounted to 1.063 and against in migration $\left(\mathrm{Y}_{4}\right)$ of 0.545 .

The direct effects of economic transformation $\left(\mathrm{Y}_{1}\right)$ on the transformation of the workforce $\left(\mathrm{Y}_{2}\right)$ amounted to 0.537 , the income per capita $\left(\mathrm{Y}_{3}\right)$ of 0.015 , and the in migration (Y4) 0,024. Indirect effects of economic transformation ( $\left.\mathrm{Y}_{1}\right)$ of the income per capita (Y3) amounted to 0.013 and against in migration $\left(\mathrm{Y}_{4}\right)$ 0. Total investment securities $\left(\mathrm{X}_{2}\right)$ with the transformation of the economy $\left(\mathrm{Y}_{1}\right)$ of 0.966 , the transformation of labor $\left(\mathrm{Y}_{2}\right)$ of 1, 27, the income per capita $\left(\mathrm{Y}_{3}\right)$ amounted to 1.063 and against in migration $\left(\mathrm{Y}_{4}\right)$ of 0,024 . 
The direct effects of the transformation of labor $\left(\mathrm{Y}_{2}\right)$ of the income per capita $\left(\mathrm{Y}_{3}\right)$ of 0.024 , and the in migration $\left(\mathrm{Y}_{4}\right)$ 0.002. Indirect effects of the transformation of labor $\left(\mathrm{Y}_{2}\right)$ against in migration $\left(\mathrm{Y}_{4}\right)$ 0.018. The total effect of the transformation of labor $\left(\mathrm{Y}_{2}\right) 0,024$ against income per capita $\left(\mathrm{Y}_{3}\right)$ amounted to 0.024 and against in migration $\left(\mathrm{Y}_{4}\right)$ of 0.02 .

\section{b. Findings}

Empirical substantiation of the hypothesis proposed in this study are also described in this chapter, then the empirical evidence compared with the results of previous studies. The results of the comparison will bring strengthening-reinforcement of existing theories or bring new empirical evidence that can be used as a reference to formulate a new theory.

\section{A. Influence Analysis and Implementation of Government spending on economic transformation, the transformation of labor, per capita income and in migration of the population.}

As described in the previous chapter to determine whether a variable significantly influence the other variables are based on the value of the critical ratio $(t)$ compared with $t$ table with $\alpha=5 \%$. If the critical ratio is greater than $t$ table, we conclude that these variables have a significant effect. It can be concluded that the hypothesis is accepted, and vice versa if smaller than $\mathrm{t}$ table then the hypothesis is rejected.

Based on the provisions mentioned above, following proper assessment of the causal relationships that occur in the following research models.

\section{A1.a. Direct influence of government spending towards economic transformation.}

Based on the computation results in the previous chapter is known that the regression coefficient of 55.8 and critical ratio or t 5,574 t value is greater than t table with $\alpha=5 \%$, which is 1.96. These results indicate that government spending has a positive and significant impact on the economic transformation in the province of Moluccas. Thus, the first hypothesis government spending on this research that government spending affect the economic transformation is evident. It can be said the higher government spending will make the growing economic transformation.

The results are consistent with the theory and previous empirical studies that reveal the influence of government expenditure to economic transformation.

Economic development will have an impact on economic growth. The economic growth experienced by almost every country always accompanied by changes in the structure of the economy, namely the decline in the share of the agricultural sector and the increasing share of non-agricultural sector, both in terms of contribution to Gross Domestic Product (GDP), as well as the absorption of employment (Dirgantoro, 2009).

From the results of this study indicate that government spending on cities and districts sampled was good and very influential to support the creation of economic transformation, and it is evident that only the West Southeast Moluccas district and Aru district that still has not happened economic transformation.

\section{A1.b. Direct Effect of Government spending on labor Transformation}

Based on the computation results in the previous chapter is known that the regression coefficient of 11.1 and critical ratio or $1,167 \mathrm{t}$ value is smaller than $\mathrm{t}$ table with $\alpha=5 \%$, which is 1.96. These results indicate that government spending has no effect for the transformation of the workforce in the province of Moluccas. Thus, the second hypothesis government spending in this study the effect of government spending on the transformation of labor is unacceptable. The results of this study do not correspond with some previous empirical studies that revealed 
their direct influence of government spending with the transformation of the workforce. These findings relate to the results of other findings in this study that the government spending particularly in the cities and counties in the province of Moluccas more emphasis on the development of economic activity, so that government spending directly affect the economic transformation and the next new influence or creation of the transformation of labor, So the government spending that occurs not put emphasis on the development of the real sector, but the economic sectors of society to improve the ability of the economy and incomes.

\section{A1.c. Direct influence of government spending to per capita income of the population}

Based on the computation results in the previous chapter is known that the regression coefficient of 0.015 and a critical ratio or t 9.06. T value is greater than t table with $\alpha=5 \%$, which is 1.96 . These results indicate that government spending affect the per capita income of the population in the province of Moluccas. Thus, the third hypothesis that government spending government spending affect the per capita income is acceptable. It can be argued that government spending will directly affect to increase the per capita income of the people. The results are consistent with the theory and previous empirical studies stating that government spending directly affects income per capita.

\section{A1.d. Direct influence in government spending to population migration}

Based on the computation results in the previous chapter is known that the regression coefficient of 0.024 and a critical ratio or $\mathrm{t} 5.723$. T value is greater than t table with $\alpha=5 \%$, which is 1.96 . These results indicate that the effect on the government spending in the migration of people in Moluccas province. Thus, the fourth hypothesis that government spending in government spending affect the migration of the population can be accepted. So to say the better allocation of expenditure in the government, labor migration will increase. The results are consistent with the theory and previous empirical studies that revealed that government spending in effect on labor migration.

\section{A2. Indirect Effect of Government Spending on the transformation of labor, per capita income and in migration}

The indirect effect of government spending on the transformation of the workforce through economic transformation variables in accordance with the result that there is very influential. This is consistent with the study of theory and empirical studies that prove that government spending indirect effect through economic transformation variables of a region. Thus, the government spending that could give effect to the economic transformation and then it will affect the transformation of the workforce.

Then the indirect effect of government expenditure to per capita income of the population through economic transformation positive effect. Then the indirect effect of the government spending in migras through economic transformation and a per capita income according to the results is very powerful, this agrees with the study of theory and previous empirical studies that prove it.

\section{B. Analysis and Implementation of Investment Effect Against economic transformation, transformation of labor, per capita income and in migration of the population. \\ B1.a. Effect of Direct Investment to the Economic Transformation}

Based on the computation results in the previous chapter is known that the regression coefficient of 0.966 and a critical ratio or $t 4.061$. T value is greater than t table with $\alpha=5 \%$, which is 1.96 . These results indicate that government spending has a positive and significant impact on the economic transformation in the province of Moluccas. Thus, the first hypothesis 
in this study the effect of government spending on economic transformation are acceptable. More and more investment in an area, then it will greatly affect the economic transformation of a region.

The results are consistent with the theory and previous empirical studies that prove that the investments affect the economic transformation.

\section{B1.b. Direct Impact on the Transformation Workforce Investment}

Based on the computation results in the previous chapter is known that the regression coefficient of 0.527 and a critical ratio or t $2.586 \mathrm{t}$ value is greater than t table with $\alpha=5 \%$, which is 1.96 . These results indicate that government spending has a significant influence on the transformation of the workforce in the province of Moluccas. Thus, the second hypothesis is that investment in research investment has positive and significant influence on the transformation of the workforce is acceptable. The investment will result in quite a lot of job opportunities, then naturally people will be interested to work in non-agricultural sectors that will greatly affect the transformation of the workforce.

The results are consistent with previous theoretical and empirical studies that describe their direct influence on the transformation of labor investment.

\section{B1.c. Per Capita Income Investment influence on population}

Based on the computation results in the previous chapter is known that the regression coefficient of 0.024 and a critical ratio or $t 13.217$. T value is smaller than t table with $\alpha=5 \%$, which is 1.96 . These results indicate that government spending affect the per capita income of the population in the province of Moluccas. Thus, the third hypothesis is that investment in research investment has a positive and significant effect on per capita income of the population can be, acceptable. More and more plentiful and high investments in the region will directly affect income per capita society, for many job's open and a lot of jobs that can be filled. The results are consistent with the theory and previous empirical studies that describe the effect of the investment will directly affect income per capita.

\section{B1.d. In Investing influence on migration}

Based on the computation results in the previous chapter is known that the regression coefficient of 0.002 and a critical ratio or $t 0.395$. T value is smaller than $t$ table with $\alpha=5 \%$, which is 1.96 . These results indicate that government spending has no effect on migration in population in the province of Moluccas. Thus, the fourth hypothesis is that investment in research investment have positive influence and significant impact on migration in the population can not, acceptable.

The results are consistent with previous research and theory that explains the existence of a direct influence on the investment in migration. Investments in large numbers in a region, opening an opportunity for job seekers to get in to a certain area and work in the area.

\section{B2. Effect of Indirect Investment to Transformation of labor, per capita income and population migration in}

The indirect effect of investment on the transformation of the workforce through economic transformation in accordance with the result that there is very influential. This is consistent with the study of theory and empirical studies that prove that investment indirect effect through economic transformation on the transformation of the workforce. Then the indirect effect of investment on a per capita income through economic transformation and the transformation of labor in accordance with the results is the effect then the indirect effect of 
the investment in the migration of people through economic transformation and a per capita income according to the results is very influential.

C. Effect Analysis and Implementation of economic transformation on the transformation of labor, per capita income and inclusive migration.

C1.a. Direct influence economic transformation of the transformation of labor.

Based on the computation results in the previous chapter is known that the regression coefficient of 0.528 and a critical ratio or $t 5 . t$ value is greater than $t$ table with $\alpha=5 \%$, which is 1.96. These results indicate that economic transformation has a positive and significant impact on the transformation of the workforce in the province of Moluccas. Thus, the first hypothesis of economic transformation in this study the economic transformation has positive and significant influence on the transformation of the workforce is acceptable. The higher the economic transformation taking place in the area, will have an effect on the transformation of the workforce, because of its own workers will move from agriculture to non-agricultural sectors.

The results are consistent with the theory and previous research that describes the influence of economic transformation on the transformation of the workforce.

\section{C1.b. Direct influence economic transformation of the per capita income}

Based on the computation results in the previous chapter is known that the regression coefficient of 0.015 and a critical ratio or $\mathrm{t} 9.06$. $\mathrm{T}$ value is greater than $\mathrm{t}$ table with $\alpha=5 \%$, which is 1.96 . These results indicate that economic transformation has a positive and significant impact on per capita income of the population in the province of Moluccas. Thus, the second hypothesis of economic transformation in the economic transformation of this study have positive influence and significant impact on per capita income is acceptable. The higher the economic transformation in the region will increase the per capita income of the area, because workers who originally farmed with an erratic income, will experience changes in income and tend to increase as the economic transformation happening.

The results are consistent with the theory and previous empirical studies that explain the effect of the economic transformation of the per capita income of the people.

\section{C1.c. Direct Effect of economic transformation towards inclusive of migration}

Based on the computation results in the previous chapter is known that the regression coefficient of 0.024 and a critical ratio or $\mathrm{t} 5.723$. $\mathrm{T}$ value is greater than $\mathrm{t}$ table with $\alpha=5 \%$, which is 1.96 . These results indicate that economic transformation has a positive and significant impact on the inclusive migration. Thus, the third hypothesis of economic transformation in the economic transformation of this study have positive influence and significant impact on migration in the population can be accepted. Economic transformation will likely have implications for jobs that are open, leading to job seekers from other areas will go into the area and cause an increase in the migration to an area.

The results are consistent with the theory and previous empirical studies, which explains their direct influence on the economic transformation in the region to a certain population migration.

\section{C2. Indirect Influence of the economic transformation and inclusive per capita income, migration}

The indirect effect of economic transformation towards a per capita income in accordance with the result that there is very influential. This is consistent with the study of theory and empirical studies that prove that the economic transformation indirect effect through the 
transformation of labor to per capita income. Then the indirect effect of the economic transformation in human migration through the transformation of energy and income per capita crimes in accordance with the results is very influential,

\section{Analysis and Implementation of Transformation Effect of Labor on per capita income and population migration inclusive.}

D1.a. Direct influence the transformation of labor to per capita income.

Based on the computation results in the previous chapter is known that the regression coefficient of 0.024 and a critical ratio or $\mathrm{t} 13.217$. $\mathrm{T}$ value is greater than t table with $\alpha=5 \%$, which is 1.96 . These results indicate that the transformation of the workforce has a positive and significant impact on the income per capita in Moluccas province. Thus, the first hypothesis is the transformation of the workforce in this study the transformation of the workforce has a positive influence and significant impact on per capita income is acceptable. The higher the transformation of the workforce, will allow increasing per capita income of an area. The results are consistent with the theory and previous studies that examined the impact directly to the transformation of labor per capita income.

\section{D1.b. Direct Impact Transformation inclusive employment to population migration.}

Based on the computation results in the previous chapter is known that the regression coefficient of 0.002 and a critical ratio or $t$ 0.395. T value is smaller than t table with $\alpha=5 \%$, which is 1.96 . These results indicate that the transformation of the workforce has no effect on migration In population in Moluccas province. Thus, the second hypothesis is the transformation of the workforce in this study the transformation of the workforce has a positive influence and significant impact on migration in unacceptable.

The results of this study are not in accordance with the theory and previous empirical studies. This condition is the result of the fact that in some districts the study sample economic transformation of labor is very small and this condition is also simultaneously influence in population migration

\section{D2. Indirect Influence Transformation of labor, the migration of the population In}

The indirect effect of the transformation of labor migration in the population through a per capita income in accordance with the result that there is very influential. This is consistent with the study of theory and empirical studies that prove that the transformation of labor indirect effect through the income per capita of the population migration inclusive.

\section{E. Analysis and Implementation of Direct Impact Against In per capita income, population migration.}

Based on the computation results in the previous chapter is known that the regression coefficient of 0.751 and a critical ratio or $\mathrm{t} 3.3$. T value is greater than table with $\alpha=5 \%$, which is 1.96. These results indicate that the transformation of per capita income has an influence on migration In population in Moluccas province. Thus, the per capita income hypothesis have positive influence and significant impact on migration in unacceptable. The results are consistent with the theory and previous research which reported an effect on the per capita income in population migration.

\section{c. Theoretical implications}

The findings of this study strongly influenced by the characteristics of Moluccas Province which is an archipelago of ocean larger than the mainland, so that the spread of population and development and have not been evenly distributed in all districts. These conditions resulted in government spending and investment that exist in urban districts also differ from one another. 
Likewise to variable economic transformation, which is the ratio of the GDP agricultural sector towards non-agricultural sectors, where the results of the study found that the economic transformation only occurs in the city of Ambon is the capital of the Province, and also in the districts parent long standing, but the division of districts is still low level of economic transformation, even still has not happened, and is still dominated by the agricultural sector. According to theory and previous empirical studies, economic transformation will be followed by the transformation of labor shifting from agriculture to non-agricultural sectors. This condition is somewhat at odds with the results of the research showed that in some district expansion does not occur and economic transformation is still based on agriculture, but if in search for the districts of the division created the transformation of the workforce, though small, but the transformation of the workforce is still there is, and can not be denied that the transformation of labor that occurs is the impact of the development of a region, and was followed by an increase in per capita income of the people and will ultimately draw attention to the flow in the population and labor migration to cities and counties.

The research found that government spending has no effect on the transformation of the workforce, but indirectly through the transformation of economic power affect the transformation of the workforce. These findings indicate that government spending particularly in the cities and counties in the province of Moluccas more emphasis on the development of economic activity, so that government spending directly affect the economic transformation and the subsequent creation of new influence or transformation of labor. So the government spending that occurs not put emphasis on development of the real sector, but the economic sectors of society to improve the ability of the economy and incomes.

From the research also found that the transformation of labor does not affect the migration of the population and workers in all provinces of Moluccas, but indirectly through the variable income per capita influence in migration. This condition if in a deeper analysis is the impact of the transformation of labor that occurs is a transformation occurring in cities and counties in the province of Moluccas and is based on the results of the study do not impact or affect in migration but indirectly based on the amount of income per capita in the city and county will allow it to affect migration in the population and labor force entry to a certain area, in this case the province of Moluccas.

\section{d. Policy Implications}

The policy of government spending needs to be increased then the economic transformation will occur, which in turn will keep pushing the economic dynamics that welfare in Moluccas region continues to increase, Investment Policy should be improved for the development of non-agricultural sectors that will support sustainable economic transformation, especially in the districts of the division that is unprecedented economic transformation and the policy in relation to the transformation of the workforce needs to be increased, given the economic value of the non-agricultural sectors is greater, and at the same time an economic opportunity, so it will be interesting in the migration to the province of Moluccas.In conjunction with the economic policy community is that per capita income of the people needs to be improved, so that the public welfare can be achieved and the power of dance to the economy in the migration to the province of Moluccas.

\section{Conclusions}

Government spending is positive and significant impact on the transformation of the economy, per capita income and in the migration of people in Moluccas province, but have no direct impact on the transformation of the workforce, but indirectly through the variable effect of economic transformation. Investment positive and significant impact on economic transformation, the transformation of labor, per capita income and in the migration of people 
in Moluccas province. Transformation of the economy positive and significant impact on the transformation of labor, per capita income and in the migration of people in Moluccas province. 4. Transformation of labor and significant positive effect on per capita income, but does not affect the migration of the population in Moluccas Province and the per capita income positive and significant impact on migration in the population in the province of Moluccas.

\section{REFERENCES}

Adisasmita, R, 2009., Pengelolaan Pendapatan dan Anggaran Daerah, Pusat Pengembangan Keuangan dan Ekonomi Daerah (PPKED), Fakultas Ekonomi Universitas Hasanudin, Makasar.

Adisasmita, R, 2009., Pembiayaan Pembangunan Daerah, Pusat Pengembangan Keuangan dan Ekonomi Daerah (PPKED), Fakultas Ekonomi Universitas Hasanudin, Makasar.

Alesina, A. S. Ardagna, R. Perotti, and F Schianterelli, 2002. Fiscal Policy, Profit, and Investment, The American Economic Review, 92 (3): 571-589.

Amir, H .dan S, Nazara, 2005. Analisis Pertumbuhan Struktur Ekonomi (Economic Landscape) dan Kebijakan Strategi Pembangunan Jawa Timur Tahun 1994 dan 2000. Analisis Indput-Output. Jurnal Ekonomi dan Pembangunan Indonesia, 5(02): 37-55.

Amit, K. Bhandari, Almas Heshmati, 2005, Labour Use an its Adjustment in India Manufacturing Industries, 11 ww.ssrn.com.

Ananta, Aris, 1990. Ekonomi Sumberdaya Manusia, Lembaga Demogri Fakultas Ekonomi Universitas Indonesia, Jakarta.

Antoni, S, 2007. Pengaruh Investasi dan Konsumsi terhadap Penyerapan Tenaga Kerja pada Sektor Industri di Sumatera Utara, www. iibrary. usu.ac.Id.

Arsjad, Nurjaman, B. Kusumanto, Y. Prawirosetoto, 1992, Keuangan Negara. Jakarta: Intermedia.

Asher, Mukul G, dan Amin Tyabji, 1978. 'An Analysis on Budgetary Expenditures of The National Government The Philippines', Ekonomi dan Keuangan Indonesia, Vol XXVI, No. 1

Azis, Iwan Jaya. 1995. (ed. Marsudi D). Ilmu Ekonomi Regional dan Beberapa Aplikasinya di Indonesia, Jakarta: Penerbit FE-UI.

Backer, G. S. 1971. The Economic of Discrimination, The University of Chicago Press, Chicago.

Becker, G. S. 1993. Human Capital, A Theoritical an Empirical Analysis with Special Reference to Education. $3^{\text {rd }}$ Edition, Chicago Press. Chicago.

Bellante, D and M Jackson, 1900. Ekonomi Ketenagakarjaan. Terjemahan Lembaga Penerbitan Fakultas Ekonomi, Universitas Indonesia, Jakarta.

Booth, 1988. "Central Government Funding of Regional Government Expenditure in Indonesia Post Achivement and Future Prospect” in Nick Devas, 1988. Financing Local Government in Indonesia. Institute of Local Government Studies, University of Birmingham.

Branson, W.H. and J.M Litvack, 1976. Macroeconomics, $\underline{\text { Harper International Edition, Harper }}$ \& Row, Publisher, New York.

Branson, W.H. 1979. Macroeconomic Theory and Policy, Second Ed. Harper \& Row, Publisher, New York.

Brata, Aloysius Gunandi, 2005. Investasi Sektor Publik Lokal, Pembangunan Manusia dan Kemiskinan. Lembaga Penelitian Universitas Atma Jaya, Yogyakarta.

Budiharsono, S. 1996. Transformasi Struktural dan Pertumbuhan Ekonomi Antar Daerah di Indonesia, Disertasi Doktor, Program Pascasarjana Institut Pertanian Bogor.

Case and Fair, 2004. Prinsip-Prinsip Ekonomi Makro, Edisi Kelima, PT. Indeks., www.prenhall.com.casefair. Jakarta. 
Chambers, R.G and J. Quiggin, 2005. Output Price Subsidie in a Stochastic World. American Journal af Agricultural Economics, 87(7):501-508.

Cho, G, I.M, Sheldon and S. McCorriston, 2002. Exchange Rate Uncertainty and Trade. American Journal of Agricultural Economics. 84 (4): 931-942.

Clark, C. 1951. The Condition of Economic Progress. Macmillan \& Co Ltd, London.

Cheng, B.S., and T.W. Lai. 1997. Government expenditure and economic growth in South Korea: A VAR Approach. Journal of Economic Development, 22 (1)

Davey, KJ. 1988, (penerjemah Amanullah) Pembiayaan Pemerintah Daerah. Praktek-praktek Internasional dan Relevansinya bagi Dunia Ketiga. Jakarta; Penerbit Universitas Indonesia (UI-Press).

Dèmurger, S. 2001. Infrastructure development and economic growth: An explanation for regional disparities in China. Journal of Comparative Economics, 29, 95-117.

Dornbusch, Rudiger; Stanley Fisher dan Richard Startz. 2004. Makro Ekonomi. Edisi Bahasa Indonesia, PT Media Global Edukasi, Jakarta

Fane, G. 2003. Change and Continuity in Indonesi's New Fiscal Decentralization Arrangement, Bulletin of Indonesian Economic Studies, 39(1): 159-176.

Firman, T. 1994. Migrasi Antar Propinsi dan Pengembangan Wilayah di Indonesia. Majalah Prisma. No.7. LP3ES. Jakarta.

Frenkel, J.A., and A. Razin. 1996. Fiscal Policies and Growth in the World Economy. Third Edition. London: The MIT Press.

Fukuchi, T. and S. Tokunaga, 1999. Simulation Analysis of Exchange Rate Dynamics: The Case of Indonesia. The Developing Economic, 37(1): 35-58.

Harjanti, Erni Setyo, 2005. Pengaruh Pengeluaran pemerintah, investasi dan Pertumbuhan ekonomi terhadap Penyerapan Teaga Kerja di Kota Salatiga Provinsi Jawa Tengah Tahun 1989-2003. Pascasarjana Universitas Gadjah Mada Yogjakarta

Jones, G.W. dan Mamas, I Gde. 1996. The Changing Employment Structure of Extended Jakarta Metropolitas Region, dalam BIES. Vol.32. No.1. pp. 51-70.

Keban, Y.T. 1994. Niat Bermigrasi di Tiga Kota, Determinan dan Intervensi. Majalah Prisma. No.7. LP3ES. Jakarta.

Mahi, B. Raksaka. 2004, Local Government Financing Strategis ini Regional Development in The Era of Decentralization: Growth, Poverty and The Environment. Editor Armida Alisjahbana dan Babbang Bridjonegoro, IRSA an UNPAD Press.

Madris, 2007. Karakteristik Dinamik Tenaga Kerja Edukatif: Analisis Kinerja, Fungsi Upah dan Fungsi Penewaran Tenaga Kerja Dosen Perguruan Tinggi Negri Makasar. Disertasi Doktor, Program Pascasarjana Universitas Hasanudin.

Makmum 2004. Pengaruh Ketersediaan Tenaga Kerja dan Pembentukan nilai Tambah Terhadap Investasi di Sektor Industri. (Studi Kasus Kota Batam). Kajian Ekonomi dan Keuangan, Vol 8,No 1 Maret.

Mankiw,N. Gregory, 2003, Teori Makroekonomi. Edisi Kelima, Erlangga, Jakarta

Mellor, J.W, 1966. The Economic of A gricultural Development, Ithaca, NY: Cornell University Press.

Munir, R. 2000. Migrasi. dalam Lembaga Demografi FEUI. Dasar-dasar Demografi: edisi 2000. Lembaga Penerbit UI, Jakarta.

Musgrave, Richard. A. \& Peggy. B. Musgrave, 1989. Public Finance in Theory and Practice. $5^{\text {th }}$ ed. International Edition Singapore: Mc Graw-Hill Book. Co.

Prasetiantono, A. Tony. 1995. 'Dilema Kebijakan Sektor Publik' dalam Agenda Ekonomi Indonesia, Jakarta: PT Gramedia. Hal. 284-288.

Prasetiantono, A. Tony, 1994. Kebijakan Ekonomi Publik di Indonesia: Substansi dan Urgensi. Kumpulan Tulisan Guritno Mangkoesoebroto. Jakarta: PT Gramedia Pustaka Utama. 
Premchand, A. 1983. Government Budgeting and Expenditure Controls: Theory and Practice, Wasington DC: International Monetary Fund.

Purnomo, B. S, 2009. Obligasi Daerah: Alternatif Investasi bagi Masyarakat dan Sumber Pendanaan bagi Pemerintah Daerah, Penerbit Alfabeta, Bandung.

Rusli, S. 1996. Pengantar Ilmu Kependudukan: edisi Revisi. LP3ES. Jakarta.

Subiyantoro, H. dan Riphat, S. 2004. Kebijakan Fiskal; Pemikiran, Konsep, dan Implementasi. Penerbit Kompas, Jakarta.

Sulistyaningsih, E. 1997. Dampak Perubahan Struktur Ekonomi terhadap Struktur Pengerapan Tenaga Kerja di Indonesia 1980-2019; Suatu Pendekatan Input-Output Disertasi Doktor, Program Pascasarjana Institut Pertanian Bogor, Bogor.

Sumaryadi I.N, 2005. Perencanaan Pembangunan Daerah Otonom \& Pemberdayaan Masyarakat. Penerbit, Citra Utama, Jakarta.

Sukirno, S. 2007. Makroekonomi Modern, Perkembangan Pemikiran dari Klasik hingga Keynesian Baru, PT. Raja Grafindo Persada, Jakarta.

Swasono dan Sulistyaningsih,1993. Pengembangan Sumber Daya Manusia. Jakarta. CV. Izufa Gempita

Suparmoko, M. 2002. Ekonomi Publik, Untuk Keuangan dan Pembangunan Daerah, Penerbit Andi: Yogyakarta.

Tambunan, M. 2009. Menggagas Perubahan Pendekatan Pembangunan: Menggerakkan Kekuatan Lokal dalam Globalisasi Ekonomi, Graha Ilmu, Jakarta.

Treadgold, M.L. 1996. Macroeconomic Policy Issues in the Asia-Pacific Economies, in Dilip K. Das (Ed.), Emerging Growth Pole: The Asia-Pacific Economy. Singapore: Prentice Hall

Young, E. 1994. Migrasi. dalam Lucas D., dkk. Pengantar Kependudukan. Gadjah Mada University Press, Yogyakarta.

Zhang, T., and H. Zou. 2001. The Growth Impact of Intersectoral and Intergovernmental Allocation of Public Expenditure: With Application to China and India. China Economic Review, 12, 58-81. 